\title{
Assessment of Mean Platelet Volume in Acromegaly and its Relation With Disease Outcome
}

Authors 1) Berrin Çetinarslan 2)Özlem Zeynep Akyay 3)Alev Selek 4) Adnan Batman 4) Zeynep Cantürk 5)i̇lhan Tarkun

Hospital: Kocaeli Universty Endocrinology and metabolism Section, Kocaeli, Turkey

\section{Objectives:}

Acromegaly is associated with increased risk of coronary atherosclerosis and cardiovascular mortality. Changes in coagulation and fibrinolysis markers in acromegalic patients have been shown to indicate increase in the risk of developing cardiovascular disease. Mean platelet volume(MPV) is a marker of platelet function and activity, and increased MPV is an independent risk factor of myocardial infarction and thrombotic events. In this study, we examined the levels of MPV in acromegalic patients before and after treatment and also compared with a control group

\begin{abstract}
A total of 80 patients ( 24 were diabetic) treated in our clinic with the diagnosis of acromegaly between 2009 and 2014 and 65 (23 were diabetic) age- and gender-matched nonacromegalic controls were reviewed retrospectively. Demographic data of all subjects, and postoperative cure and remission with medical management among acromegalic patients were recorded. Preoperative and postoperative MPVvalues as well as MPV values after controlled disease in patients with medical treatment were compared. In both groups $\mathrm{HbAlc}$ levels and their relationship with MPV were also evaluated
\end{abstract}

Table 1. Comparison of demographic data and MPV values between groups

\begin{tabular}{|c|c|c|c|c|c|}
\hline & \multicolumn{2}{|c|}{ Acromegaly $(n=80)$} & \multicolumn{2}{|c|}{ Control $(n=65)$} & PValue \\
\hline Gender (F/M) & \multicolumn{2}{|l|}{$37 / 43$} & \multicolumn{2}{|l|}{$33 / 32$} & 0,32 \\
\hline Age & \multicolumn{2}{|c|}{$46( \pm 11)$} & \multicolumn{2}{|c|}{$48( \pm 11)$} & $0,24 \mid$ \\
\hline MPV & \multicolumn{2}{|c|}{$8,62( \pm 1,48)$} & \multicolumn{2}{|c|}{$7,77( \pm 0,85)$} & $<0,001$ \\
\hline \multirow[t]{2}{*}{$\begin{array}{l}\text { HbA1c\% (for } \\
\text { diabetics) }\end{array}$} & \multicolumn{2}{|c|}{$7,1( \pm 2,8)$} & \multicolumn{2}{|c|}{$6,9( \pm 1,1)$} & 0,64 \\
\hline & DM & nonDM & DM & nonDM & \\
\hline MPV & $\begin{array}{l}8,5 \\
( \pm 1,40)\end{array}$ & $\begin{array}{l}8,68 \\
( \pm 0,78)\end{array}$ & $\begin{array}{l}7,65 \\
( \pm 1,50)\end{array}$ & $\begin{array}{l}7,83 \\
( \pm 0,90)\end{array}$ & $<0,05^{*}$ \\
\hline
\end{tabular}

* There is no significant differences of DM and nonDM between aroups
Table 2. Evaluation of outset MPV and post- treatment MPV of acromegaly patients

\begin{tabular}{l} 
Table 2. Evaluation of outset MPV and post- treatment MPV of acromegaly patients \\
\begin{tabular}{|l|l|l|l|l|}
\hline & Preop MPV & Postop MPV & $\begin{array}{l}\text { MPV after } \\
\text { surgery+medical } \\
\text { treatment }\end{array}$ & P value \\
\hline $\begin{array}{l}\text { All acromegaly } \\
\text { group }\end{array}$ & $8,62( \pm 1,48)$ & $8,1( \pm 1,50)$ & $7,5( \pm 1,90)$ & $<0,000^{*}$ \\
\hline $\begin{array}{l}\text { The group which is } \\
\text { curing provided } \\
\text { after surgery }\end{array}$ & $8,52( \pm 1,46)$ & $7,5( \pm 1,02)$ & - & $<0,000$ \\
\hline $\begin{array}{l}\text { The group which is } \\
\text { under control with } \\
\text { surgery+medical } \\
\text { treatment }\end{array}$ & $8,66( \pm 1,56)$ & $8,02( \pm 1,36)$ & $7,38( \pm 1,03)$ & $<0,000^{*}$ \\
\hline $\begin{array}{l}\text { The group which is } \\
\text { uncontrolled with } \\
\text { surgeery+medical } \\
\text { treatment }\end{array}$ & $8,26( \pm 0,86)$ & $8,05( \pm 0,8)$ & $7,38( \pm 0,63)$ & $0,64-0,32$ \\
trespectively
\end{tabular} \\
\hline
\end{tabular}

\section{Results:}

MPV values were significantly higher in both the diabetic and non-diabetic acromegaly patients compared with the control subjects. Postoperative MPV values were significantly reduced compared to preoperative values in patients cured after surgery. Patients who achieved disease control with medical therapy after the failure of surgical intervention demonstrated MPV values similar to those reported in patients cured with surgery. When MPV values at presentation were evaluated in the acromegaly and control groups, it was shown that age, gender and presence of diabetes mellitus, had no effect on MPV values.

\section{Conclusions:}

MPV can be considered as a marker for atherothrombotic process and prognosis in acromegaly. Our findings suggested MPV would be a beneficial prognostic marker of cardiovascular complications in patients with acromegaly

\section{References:}

1) Kartal I, Oflaz H Pamukc u B, et al. Investigation of early atherosclerotic changes in acromegalic patients. Int $J$ ClinPract. 2010;64(1):39-44. 2) Brevetti $G$, Marzullo $P$, Silvestro $A$, et al. Early vascular alterations in acromegaly. J ClinEndocir 2002;87(7):3174-3179 3) Erem C, Nuhoglu I, Kocak M, et al. Blood coagulation and fibrinolysis in patients with acromegaly: increased plasminogen activator inhibitor-1 (PA1), decreased tissue factor pathway inhibitor (TFPI), and an inverse correlation between growth hormoneand TFPI. Endocrine. 2008;33(3):270-276 